\title{
Drainage Bed: A Natural System for WTP Sludge Dewatering and Drying with Different Coagulant Chemicals in Tropical Countries
}

\author{
Marcelo M. Barrosoํ, Cali L. Achon²*, Renan F. Reis³, João S. Cordeiro4 \\ ${ }^{1}$ ISITEC - Higher Institute of Innovation and Technology, São Paulo, Brazil \\ ${ }^{2}$ EESC/USP_University of São Paulo at São Carlos School of Engineering, São Carlos, Brazil \\ ${ }^{3}$ UFSCar-Federal University of São Carlos, São Carlos, Brazil \\ ${ }^{4}$ UFSCar-Federal University of São Carlos, São Carlos, Brazil \\ Email: ${ }^{*}$ caliachon@bol.com.br
}

Received 24 April 2014; revised 21 May 2014; accepted 16 June 2014

Copyright (C) 2014 by authors and Scientific Research Publishing Inc.

This work is licensed under the Creative Commons Attribution International License (CC BY).

http://creativecommons.org/licenses/by/4.0/

(c) (7) Open Access

\begin{abstract}
This study seeks to evaluate the mechanisms for dewatering sludge from Water Treatment Plants (WTP) in a natural system that uses nonwoven polyester geotextile blankets named Drainage Bed (DB). Dewatering mechanisms are divided into two stages: Drainage and Drying Phases. For the Drainage Phase, the results showed that the solids content of the Aluminum Sulfate sludge reached $8.9 \%$ to $18.3 \%$ and the PACl sludge $1.8 \%$ to $6.5 \%$, the volume reduction on this phase exceeding $50 \%$ and $74 \%$, respectively. The final solids content, after the Drying Phase, was greater than 28\%, reaching 90\%. In the Drainage Phase the lower the Surface Application Rate-SAR $\left[\mathrm{kg} / \mathrm{m}^{2}\right]$ is, the greater the drainage flow will be. In the Drying Phase, moisture and insolation were key factors in drying sludge. Thus, the Drying Phase in the DB takes special attention for being virtually nonexistent in dewatering technologies in a closed system (confined) without exposure to solar energy. The use of the DB as a natural system for dewatering WTP sludge in tropical countries proved to be a promising alternative, because of its efficient removal of water from sludge coupled with operational simplicity and low costs, provided there is area available.
\end{abstract}

\section{Keywords}

Sludge, Dewatering, Drying, Drainage Bed (DB), Geotextile Blanket

\footnotetext{
*Corresponding author.
}

How to cite this paper: Barroso, M.M., Achon, C.L., Reis, R.F. and Cordeiro, J.S. (2014) Drainage Bed: A Natural System for WTP Sludge Dewatering and Drying with Different Coagulant Chemicals in Tropical Countries. Journal of Water Resource and Protection, 6, 1029-1036. http://dx.doi.org/10.4236/jwarp.2014.611097 


\section{Introduction}

The vast majority of Water Treatment Plants (WTPs) worldwide seek urgent solutions for proper disposal of waste generated in decanters and filters particularly.

In Brazil, as in other tropical countries, it is prohibited to release WTP sludge into bodies of water, according to national legislation [1] and [2]. However, this practice is common in most WTPs [3], making the development of solutions for the proper disposal of this waste an urgent matter.

The method and interval of sludge removal from decanters also pose serious problems in that it is performed manually and intermittently at intervals that can extend for more than 30 days. The time interval for sludge removal from WTPs of full cycle could reach 180 days [4]. The manual operation of sludge removal using jets of high-pressure water and wooden squeegees causes operators to be in direct contact with this material [5] and its solids content to vary considerably.

Efforts to minimize the generation of waste must be a priority. However, it does not eliminate the need for drainage systems, either natural or mechanical, necessary to reduce the volume of sludge generated and to facilitate its disposal. Natural systems include sludge lagoons, drying beds, Draining Bags (BAGs) and Drainage Beds (DBs). Among mechanic systems there are: centrifuges, filter presses, dewatering presses, etc.

After passing through a dewatering system, dewatered sludge can be taken to post-treatment via thermal systems, which promote drying of the material. Thermal systems may be natural or mechanical, such as natural thermal drying, drying ovens, mechanical thermal dryers, incineration, etc.

In sludge lagoons the top layer of sludge exhibits good drying, which does not occur in the lower layers [6] and [7].

Tropical countries, such as Brazil, have advantages in the deployment of nonmechanical dewatering systems, since area availability and climate favor natural methods of water removal [8].

Accordingly, the Drainage Bed (DB) was developed in Brazil [9]—a nonmechanical system (exposed to atmospheric pressure) using as filtering medium nonwoven geotextile blankets, a result of research in laboratories through the evolution of traditional drying beds, which filtering medium is sand [10], as illustrated in Figure 1.

The advantages of the Drainage Bed are mainly due to improved efficiency in draining the free water present in the sludge and the possibility of thermal drying of dewatered sludge by evaporation, through the use of natural (solar) energy.

In this technology, the mechanisms of filtration through synthetic blankets should receive special attention. There are two basic mechanisms of filtration through synthetic blankets, based on the different conditions of the solid-geotextiles interaction: filtration of suspended particles and filtration in porous media [11], [12] and [13].

Thus, the efficiency of a filtering system consisting of geotextiles to maintain its draining/filtering capacity over time is closely related to the occurrence of clogging.

Clogging occurs when particles carried in the flow are deposited on the filtering interface, or led into it, creating an area of lower permeability than in the free-flow region before the filter, resulting in alterations on the properties of the geotextile fabric over time. This can occur by blocking, blinding and clogging [14]. The clogging phenomenon directly affects the draining ability of the porous medium where the flow occurs. Nevertheless, about $75 \%$ of the pores in geotextile blankets can get clogged without having operability compromised [12].

The dewatering of WTP sludge by DBs through the separation of the liquid phase (free water) and solid phase (particles) can be understood as filtration of suspended particles (Table 1). The liquid phase consists of fractions of water: free water, interstitial water, vicinal (or surface) water and bound (or hydration) water [15] and [16]. For the removal of each water fraction, it is required to use a given intensity of energy.

The Drying Phase comprises the step intended to remove the nondrained water in the sludge mass to an unsaturated gaseous medium, such as air, through thermal vaporization [17].

The reduction of sludge volume in two different natural systems, comparing the sludge lagoons system from a conventional WTP of full cycle to the DB developed by Cordeiro [9], was analysed. The investigation showed the difficulties and long-time (months) necessity for water removal in sludge lagoons, while the DB showed a 75\% to $85 \%$ volume reduction in just seven days [18].

The results of research and implement the DB in real scale, in the municipality of Cardoso, São Paulo State, Brazil, showed high performance dewatering, with a $98 \%$ reduction of residue volume and quality of drained (turbidity < $1.0 \mathrm{uT}$ ) with satisfactory results [19].

This study seeks to evaluate the mechanisms of dewatering WTP sludge in a natural system that uses geotextile 


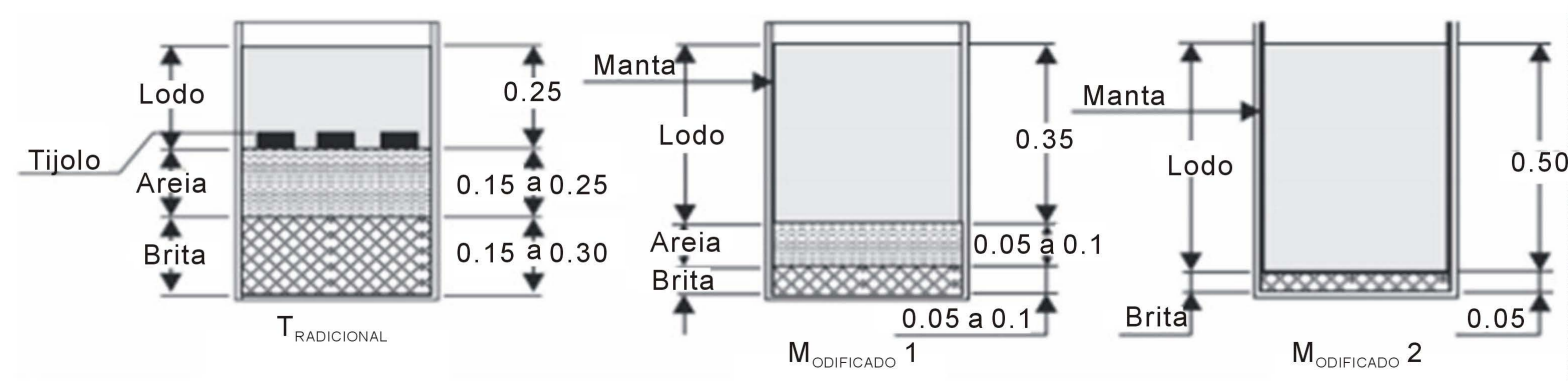

Figure 1. Illustrative schemes of traditional and modified systems 1 and 2 (Drainage Bed) as proposed by Cordeiro (1993 and 2000) [9] and [10].

Table 1. Summary of conditions and results of WTP sludge dewatering tests on Drainage Bed.

\begin{tabular}{|c|c|c|c|c|c|c|c|c|c|c|c|}
\hline Test & \multicolumn{2}{|c|}{1} & 2 & \multicolumn{2}{|c|}{3} & \multicolumn{2}{|c|}{4} & \multicolumn{2}{|c|}{$5 A$} & \multicolumn{2}{|c|}{ 5B } \\
\hline Prototype & \multicolumn{2}{|c|}{ I } & I & \multicolumn{2}{|c|}{ II } & \multicolumn{2}{|c|}{ I } & \multicolumn{2}{|c|}{ II } & \multicolumn{2}{|c|}{ II } \\
\hline Sludge (coagulant) & $\mathrm{Al}_{2} \mathrm{SO}_{4}$ & $\mathrm{PACl}$ & $\mathrm{PACl}$ & $\mathrm{Al}_{2} \mathrm{SO}_{4}$ & $\mathrm{PACl}$ & $\mathrm{Al}_{2} \mathrm{SO}_{4}$ & $\mathrm{PACl}$ & $\mathrm{Al}_{2} \mathrm{SO}_{4}$ & $\mathrm{PACl}$ & $\mathrm{Al}_{2} \mathrm{SO}_{4}$ & PACl \\
\hline Volume (L) & 25 & 25 & 20 & 8 & 8 & 55 & 55 & 8 & 8 & 8 & 8 \\
\hline $\mathrm{TS}_{\mathrm{o}}(\%)$ & 2.60 & 1.40 & 0.22 & 7.60 & 0.04 & 0.76 & 0.26 & 2.70 & 0.28 & 4.20 & 0.21 \\
\hline $\operatorname{SAR}\left(\mathrm{kg} / \mathrm{m}^{2}\right)$ & 3.43 & 1.86 & 0.23 & 7.35 & 0.04 & 2.20 & 0.76 & 2.61 & 0.27 & 4.06 & 0.20 \\
\hline $\begin{array}{c}\text { Sedimentation } \\
\text { maximum speed (mL/min) }\end{array}$ & 3.5 & 13 & 22 & 0.01 & 18.9 & 43 & 60 & - & - & - & - \\
\hline \multicolumn{12}{|c|}{ Drainage Phase } \\
\hline Drainage time $-\mathrm{T}_{\text {dra }}(\mathrm{min})$ & 300 & 60 & 60 & 480 & 30 & 300 & 60 & 120 & 10 & 120 & 10 \\
\hline Volume reduction (\%) & 74.6 & 73.8 & 80.0 & 49.1 & 95.0 & 87.9 & 95.5 & 58.1 & 96.3 & 49.8 & 96.3 \\
\hline $\mathrm{TS}_{\mathrm{o}}(\%)$ & 2.60 & 1.40 & 0.22 & 7.60 & 0.04 & 0.76 & 0.26 & 2.70 & 0.28 & 4.20 & 0.21 \\
\hline Final TS (\%) & 8.9 & 6.5 & 5.1 & 9.7 & 1.8 & 12.6 & 5.1 & 18.3 & - & 14.5 & - \\
\hline$\Delta \mathrm{TS}(\%)^{1}$ & 70.8 & 78.5 & 95.7 & 21.6 & 97.8 & 94.0 & 94.9 & 85.2 & & 71.0 & \\
\hline \multicolumn{12}{|c|}{ Drying Phase } \\
\hline $\mathrm{TS}_{1 \mathrm{dia}}(\%)$ & 13.4 & 8.8 & 13.0 & 17.3 & 13.0 & 23.4 & 16.7 & 18.3 & - & 14.5 & - \\
\hline Final TS (\%) & 30.6 & 28.4 & 91.8 & 88.9 & 53.3 & 98.0 & 46.6 & 50.3 & - & 42.3 & - \\
\hline$\Delta \mathrm{TS}(\%)$ & 56.2 & 69.0 & 85.8 & 80.5 & 75.5 & 76.1 & 64.1 & 63.6 & - & 65.7 & - \\
\hline Drying time $-\mathrm{T}_{\text {dry }}$ (day) & 7 & 7 & 6 & 7 & 2 & 6 & 2 & 7 & 1 & 7 & 1 \\
\hline TS $>30 \%$ (day) $^{2}$ & 7 & 7 & 4 & 4 & 2 & 2 & 2 & 3 & 1 & 3 & 1 \\
\hline
\end{tabular}

${ }^{1}$ Variation in solids content $\Delta$ TS $(\%)=\left[\mathrm{TS}_{0}(\%) /\right.$ Final TS $\left.(\%)\right] * 100 ;{ }^{2}$ Time in days in which solids content (TS\%) of dewatered sludge greater than $30 \%$.

blankets named Drainage Beds (DBs), and to verify the occurrence and efficiency of two distinct water removal phases: free water drainage and drying by water vaporization.

\section{Material and Methods}

In order to carry out the tests, DB prototypes and samples of raw WTP sludge were used. The blanket used in the tests is the nonwoven polyester geotextile of $600 \mathrm{~g} / \mathrm{m}^{2}$ (surface density $4.5 \mathrm{~mm}$ thick, porosity $>90 \%$, normal permeability $3 \times 10^{-1} \mathrm{~cm} / \mathrm{s}$ and $60 \mu \mathrm{m}$ opening).

In Figure 2 we have the schematic of the dewatering tests performed on DB prototypes and the variables involved.

The tests were initiated at time to, with a setting of initial solids $\mathrm{TS}_{0}(\%)$ and a measuring of the total volume of sludge applied $\left(\mathrm{V}_{\mathrm{L}}\right)$. The preset and studied control variables are presented below:

- Total time of dewatering $(\Delta \mathrm{t})=\mathrm{t}_{\mathrm{f}}-\mathrm{t}_{\mathrm{o}}=\mathrm{t}_{\text {drainage }}+\mathrm{t}_{\text {drying; }}$;

- Accumulated drained volume $(\Delta \mathrm{v})=\mathrm{V}_{\mathrm{L}}-\mathrm{V}_{\text {evaporation }}+\mathrm{V}_{\text {preciptation; }}$

- Total solids content variation $(\Delta \mathrm{TS})(\%)=\mathrm{TS}_{\mathrm{i}}-\mathrm{TS}_{0}$.

The time $t_{i}$, start of the Drying Phase and end of the Drainage Phase, was studied and characterized when the 


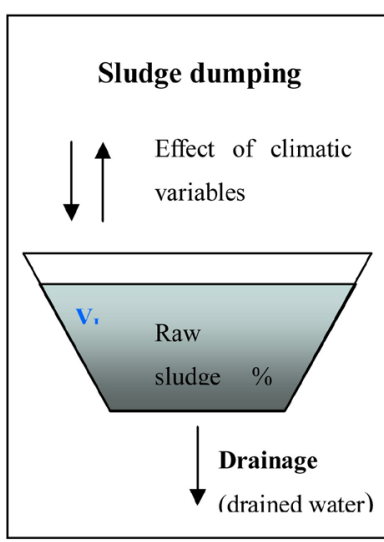

$\mathbf{t}_{0}$

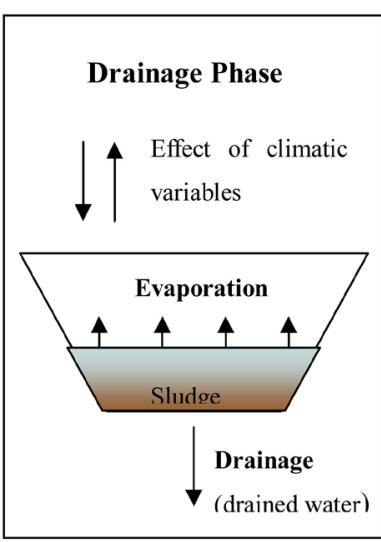

$\mathbf{t}_{\mathbf{i}}$

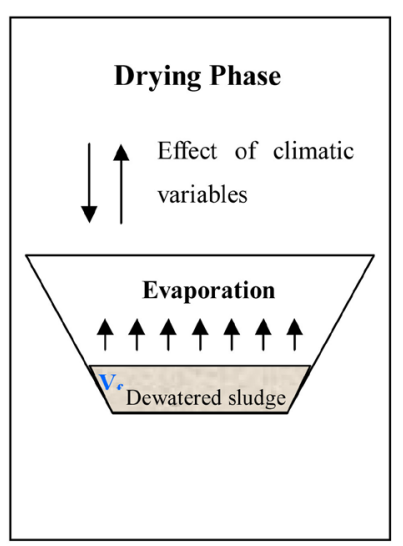

$\mathbf{t}_{\mathrm{f}}$

Figure 2. Schematic illustration of the Drainage Bed dewatering and variables involved.

drainage flow rate reached values lower than $\mathrm{Q}=0.04 \mathrm{~L} / \mathrm{mi}$, equivalent to the volume of $10 \mathrm{~mL}$ in the interval of $15 \mathrm{~min}$. The time $\mathrm{t}_{\mathrm{f}}$, end of the Drying Phase was studied and characterized either when there was no possibility to collect solids retained in the blanket or when the stipulated deadline of seven days was reached.

Six tests were performed with different samples of conventional WTP sludge which employ coagulants such as aluminum sulfate $\left[\mathrm{Al}_{2}\left(\mathrm{SO}_{4}\right)_{3}\right]$ and polyaluminum chloride (PACl).

Dewatering times $\left(t_{i}-t_{0}\right)$ were determined during the Drainage Phase and the drying time $\left(t_{f}-t_{i}\right)$, during the Drying Phase of the sludge. During the Drying Phase, climate variables were also monitored in order to provide a better understanding of the mechanisms comprising natural drying.

\section{Results and Discussion}

For all different conditions of dewatering, with raw $\mathrm{Al}_{2}\left(\mathrm{SO}_{4}\right)_{3}$ and $\mathrm{PACl}$ sludge samples, with different solids content and volumes used, the maximum drainage time was approximately eight hours, for $\mathrm{Al}_{2}\left(\mathrm{SO}_{4}\right)_{3}$ sludge, and one hour for PACl sludge, being volume reduction during the Drainage Phase superior to $50 \%$ and $74 \%$, respectively, for all tests, as Figure 3 and Figure 4 show.

The solids content after the Drainage Phase for $\mathrm{Al}_{2}\left(\mathrm{SO}_{4}\right)_{3}$ sludge ranged from $8.9 \%$ to $18.3 \%$ and for PACl sludge from $1.8 \%$ to $6.5 \%$. Final solids content, after the Drying Phase (2 to 7 days), was greater than $28 \%$ to all cases, getting closer to $90 \%$ in some tests, regardless of drying time or sludge type.

In the Drainage Phase, the value of Surface Application Rate-SAR $\left[\mathrm{kg} / \mathrm{m}^{2}\right]$ and/or Total Solids-TS [\%] proved decisive in defining the flow of initial free water drainage - the lower the SAR the higher the drainage flow for both types of sludge $\left(\mathrm{Al}_{2}\left(\mathrm{SO}_{4}\right)_{3}\right.$ and $\mathrm{PACl}$ coagulants), see Figure 5 .

The draining material used in the Drainage Bed made up of geotextile blankets showed a distribution of pore size capable of retaining flocculent, or solid particles, as evidenced by the properties of the free water drained, which showed effective removal of solids and metals from the PACl and aluminum sulfate sludge samples. Figure 6 illustrates the results of two tests, demonstrating that after five to ten minutes the turbidity of the drained water presented values close to $2.0 \mathrm{uT}$.

In the Drying Phase, climatic variables, humidity and insolation were determinants in sludge drying, see Figure 7 and Figure 8. Evaporation offered a potential means for monitoring and predicting the drying speed, especially with sludge with higher solids content.

\section{Conclusions}

The Drainage Bed (DB) was effective in the two distinct phases of sludge water removal (Drainage Phase and Drying Phase), with significant reductions in sludge volume for different sludge samples. The Drying Phase enabled the thermal drying of dewatered sludge by evaporation through the use of natural (solar) energy.

On the DB the Drying Phase takes special attention for being virtually nonexistent in other dewatering technologies, such as the use of sludge lagoons-in which there is the formation of impermeable layers of the material itself (water sandwich effect) — and in the case of Draining Bags which, for being a closed system (confined) 


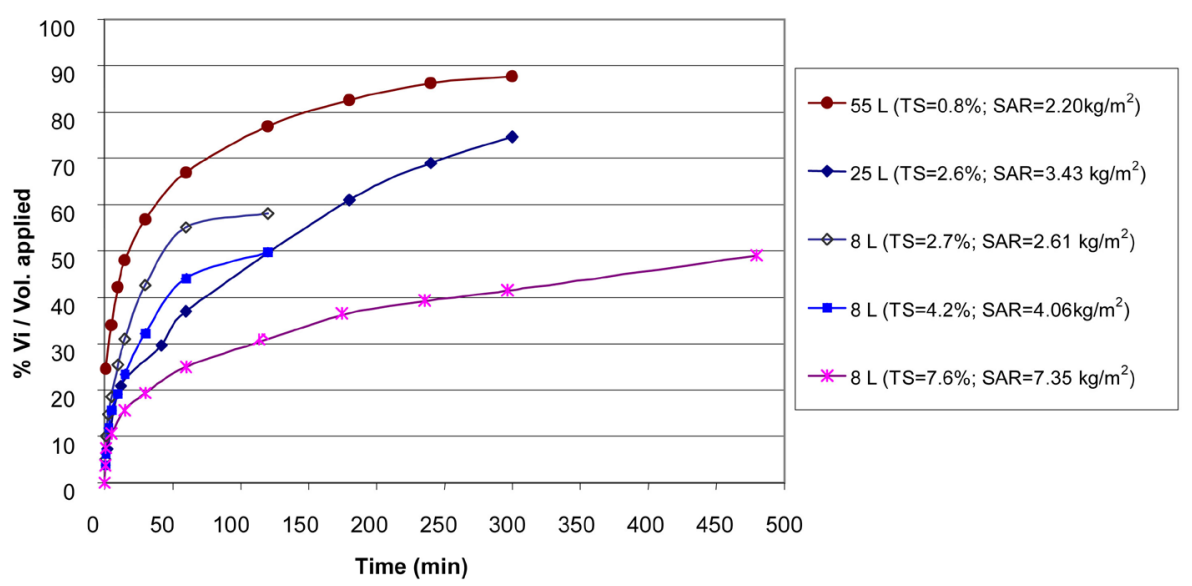

Figure 3. Cumulative volume of drained free water in dewatering tests with $\mathrm{Al}_{2}\left(\mathrm{SO}_{4}\right)_{3}$ sludge samples.

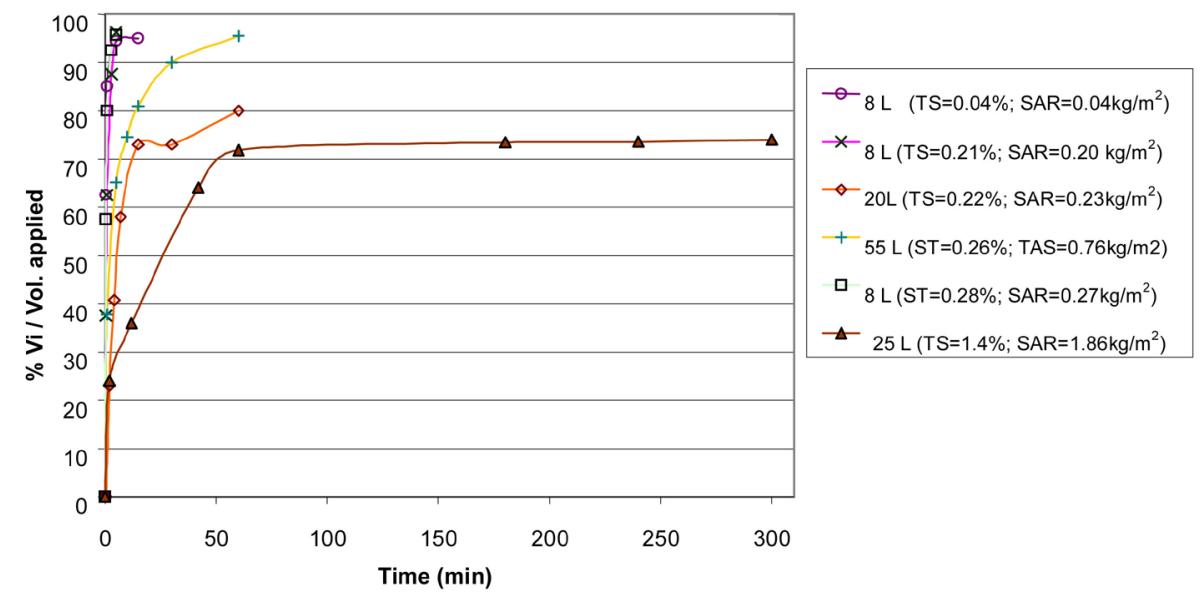

Figure 4. Cumulative volume of drained free water in dewatering tests with $\mathrm{PACl}$ sludge samples.

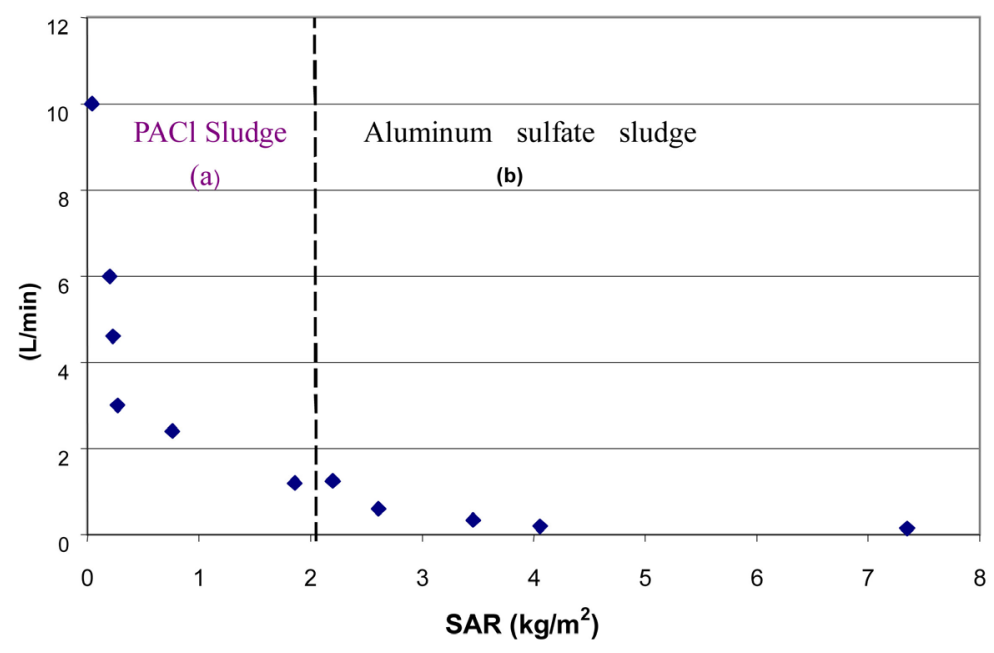

Figure 5. Relation between initial drainage flow of free water $(\mathrm{L} / \mathrm{min})$ and the values of Surface Application Rate-SAR $\left(\mathrm{kg} / \mathrm{m}^{2}\right)$ for tests conducted with a sample of PACl sludge (a) and $\mathrm{Al}_{2}\left(\mathrm{SO}_{4}\right)_{3}$ sludge (b). 


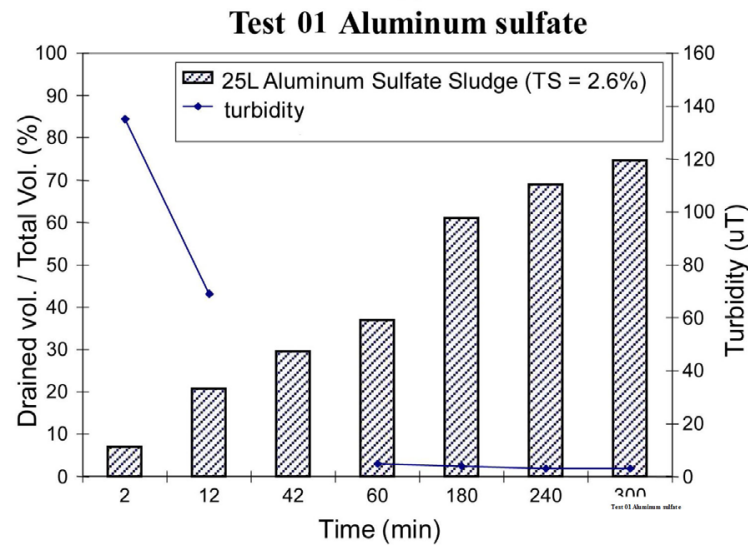

(a)

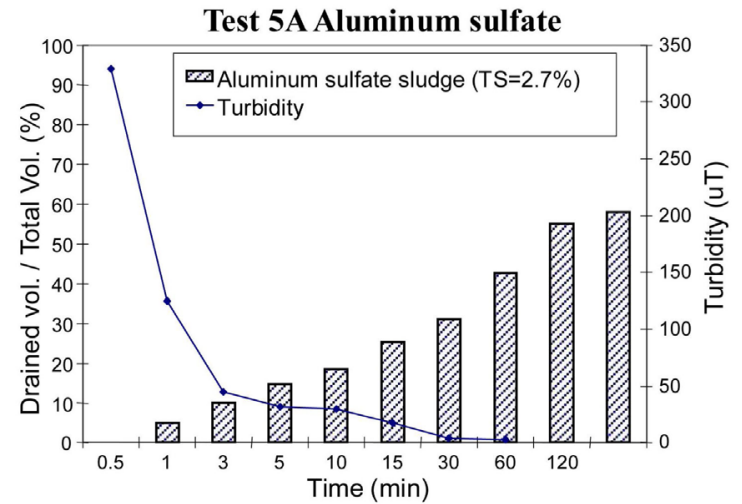

(a)

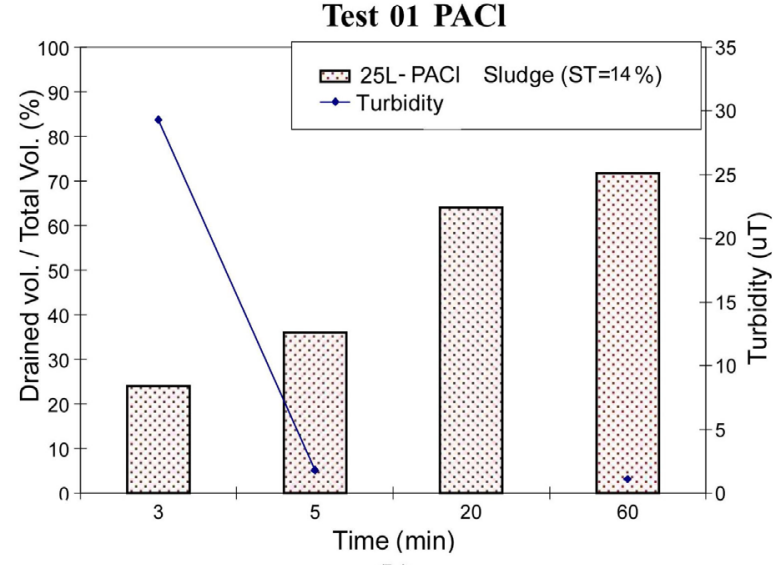

(b)

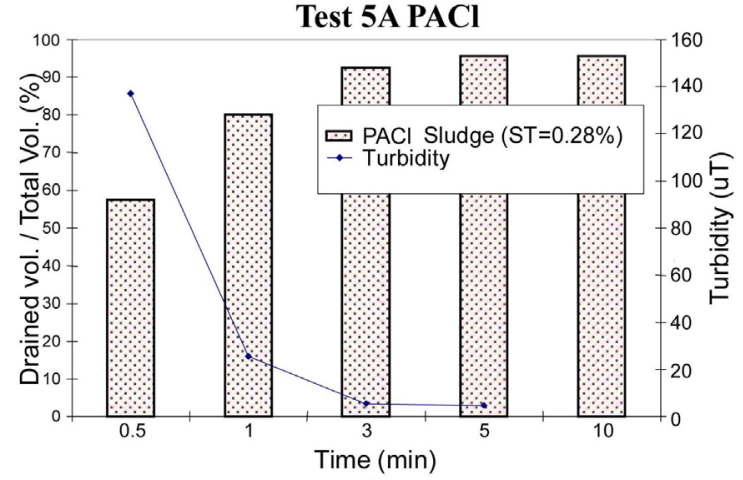

(b)

Figure 6. Variation in the values of cumulative volume of drained free water (\%) and turbidity during the Drainage Phase, for samples of $\mathrm{Al}_{2}\left(\mathrm{SO}_{4}\right)_{3}$ (a) and $\mathrm{PACl}(\mathrm{b})$.

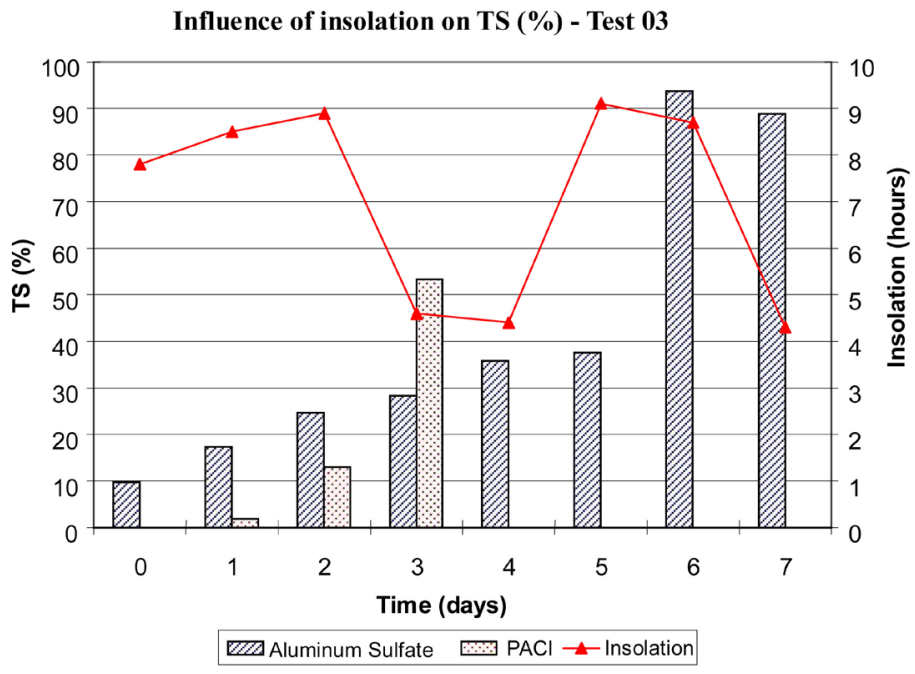

Figure 7. Variation of insolation and total solids content (\%TS) for one of the Drainage Bed dewatering tests (Drying Phase).

without exposure to solar energy, prevents the drying of the material and even reuse of the system.

The use of the DB as a natural system for dewatering WTP sludge in tropical countries proved to be a promising alternative, as a result of the efficient removal of water from sludge coupled with operational simplicity 


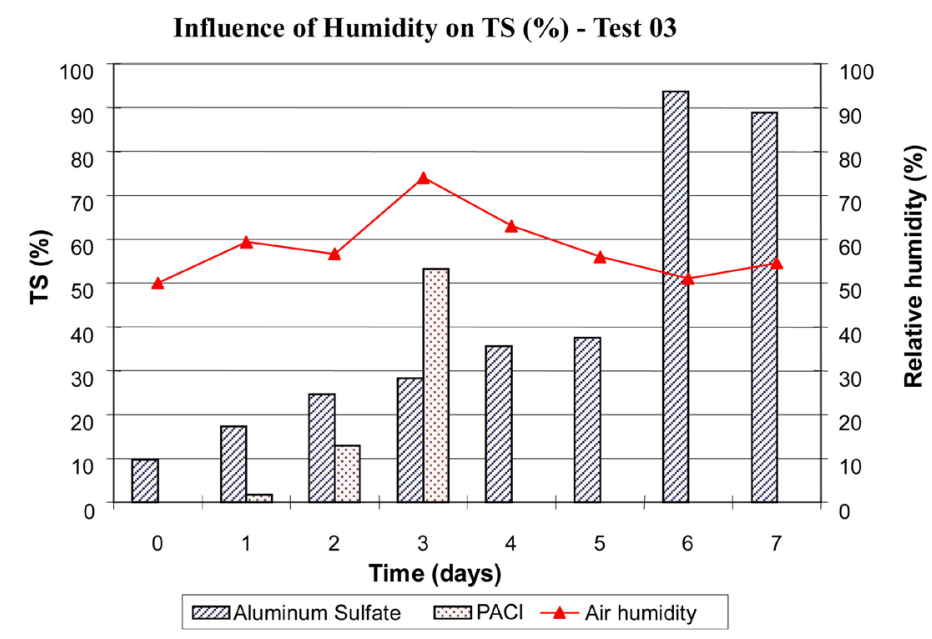

Figure 8. Variation of humidity and total solids content (\%TS) for one of the Drainage Bed dewatering tests (Drying Phase).

and low costs, provided there is area available.

\section{Acknowledgements}

I would like to acknowledge the São Paulo Research Foundation-FAPESP for its financial support.

\section{References}

[1] Brasil (1997) Presidência da República Federativa do Brasil. Legislação Federal Brasileira. Lei 9.433 de 1997.

[2] Brasil (1998) Presidência da República Federativa do Brasil. Legislação Federal Brasileira. Lei 9.605 de 1998.

[3] Achon, C.L., Barroso, M.M. and Cordeiro, J.S. (2012) Geração e destinação de lodos de estações de tratamento de água na Sub-bacia do Rio Piracicaba-Brasil. In: XV Simpósio Luso-Brasileiro de Engenharia Sanitária e Ambiental (SILUBESA), Anais, ABRH, Minas Gerais, Belo Horizonte, Brasil, I-017, 10p.

[4] Achon, C.L. (2008) Ecoeficiencia de Sistemas de Tratamento de Água a luz dos conceitos da ISO 14.001. Tese (Doutorado)—Escola de Engenharia de São Carlos, Universidade de São Paulo. São Carlos, 230p.

[5] Cordeiro, J.S., Barroso, M.M. and Achon, C.L. (2011) Resíduos de estações de tratamento de água e a saúde ambiental. In: 7th Jornadas Técnicas Internacionais de Resíduos-Energia dos Resíduos, Anais, APESB e ISWA, Instituto Superior de Engenharia do Porto, Porto, Portugal, Cód. 005, 13p.

[6] Hubbs, S.A. and Pavoni, J.L. (1974) Opimization of Sludge Dewater Ability in Sludge-Disposal Lagoa. JAWWA, Denver, 66, 658-663.

[7] Cornwell, D.A., et al. (1987) Handbook Water Treatment Plant Waste Management. AWWA, Research Foundation, Denver, 431p.

[8] American Water Works Association; American Society of Civil Engineers; U.S. Enviromental Protection Agency (1996) Management of Water Treatment Plant Residuals. American Society of Civil Engineers, New York.

[9] Cordeiro, J.S. (2001) Processamento de Lodos de Estações de Tratamento de Água (ETAs). In: Andreoli, C.V., Coord., Resíduos Sólidos do Saneamento: Processamento, Reciclagem e disposição final, Projeto PROSAB 2, Rio de Janeiro: RiMa, ABES, 282p, Cap. 5, 121-142.

[10] Cordeiro, J.S. (1993) O Problema dos Lodos Gerados nos Decantadores em Estações de Tratamento de Água. São Carlos. Tese (Doutorado)—Escola de Engenharia de São Carlos, Universidade de São Paulo, São Paulo.

[11] Sampaio, R.M.B., Vidal, D. and Urashima, D.C. (2000) Simulação do processo de carreamento e retenção de partículas em filtros têxteis. In: VI ENCITA 6rd Encontro de Iniciação Científica e Pós-graduação do ITA, São José dos Campos.

[12] Freitas, R.A.S. (2003) Comportamento de geotêxteis como filtro em resíduos-Fosfogesso e Lama vermelha. Dissertação (mestrado). COPPE/Universidade Federal do Rio de Janeiro, Rio de Janeiro, 122p.

[13] Urashima, D.C. and Vidal, D. (1995) Dimensionamento por teoria probabilística de filtros em geotextil não tecido. In: II Simpósio Brasileiro sobre Aplicação de Geossintéticos, São Paulo, 267-276.

[14] John, N.W.M. (1987) Geotextiles. Blackie, Glasgow; Chapman and Hall, New York, 347p. 
[15] Vesilind, P.A. and Hsu, C.C. (1997) Limits of Sludge Dewatering. Water Science Technology, 36, 87-91. http://dx.doi.org/10.1016/S0273-1223(97)00673-2

[16] Smollen, M. and Kafaar, A. (1994) Electroosmotically Enhanced Sludge Dewatering: Pilot-Plant Study. Water Science Technology, 30, 159-168.

[17] David, A.C. (2002) Secagem Térmica de lodos de esgoto: Determinação da umidade de equilíbrio. São Paulo. Dissertação (Mestrado), Escola Politécnica da Universidade de São Paulo, São Paulo, 151p.

[18] Achon, C.L. and Cordeiro, J.S. (2004) Análise Crítica da Implantação de Sistemas Naturais de Remoção de volume de lodo de ETA. In: XXIX Congresso Interamericano de Engenharia Sanitária e Ambiental (AIDIS), Anais, San JuanPorto Rico, cd, I-Achon-Brasil-1.

[19] Fontana, A.O. (2004) Sistema de Leito de Drenagem e Sedimentador como solução para redução de volume de lodo de decantadores e reuso da água de lavagem de filtros-Estudo de Caso-ETA Cardoso. Dissertação (Mestrado), Universidade Federal de São Carlos/UFSCar, São Carlos. 
Scientific Research Publishing (SCIRP) is one of the largest Open Access journal publishers. It is currently publishing more than 200 open access, online, peer-reviewed journals covering a wide range of academic disciplines. SCIRP serves the worldwide academic communities and contributes to the progress and application of science with its publication.

Other selected journals from SCIRP are listed as below. Submit your manuscript to us via either submit@scirp.org or Online Submission Portal.
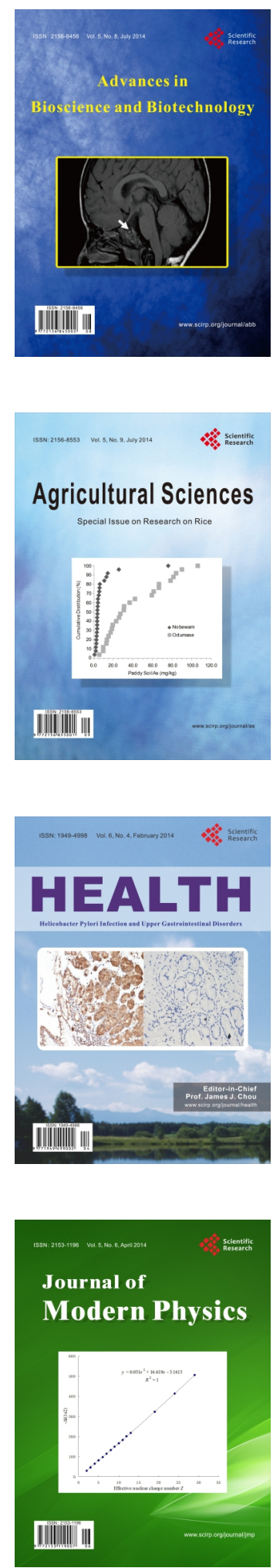
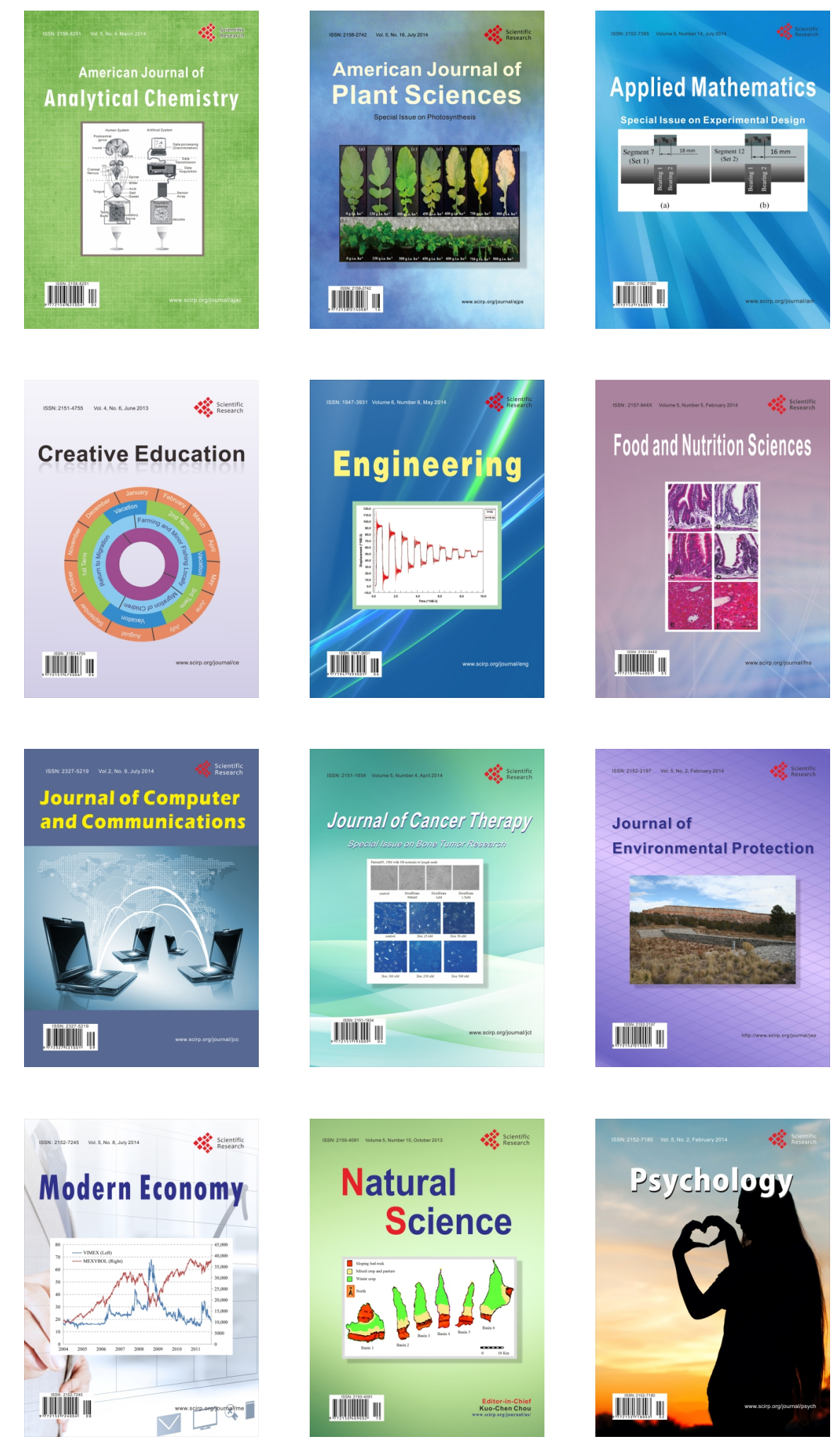